\title{
ANALISIS DAYA SAING KOPI DI DESA TLETER KECAMATAN KALORAN KABUPATEN TEMANGGUNG
}

\author{
Arif (rfanda ${ }^{1)} \&$ Yuliawati $^{1)}$ \\ ${ }^{1)}$ Fakultas Pertanian dan Bisnis, Program Studi Agribisnis, Universitas Kristen Satya Wacana Salatiga \\ JI. Diponegoro 52-60 Salatiga 50711 \\ 522014022@student.uksw.edu
}

\begin{abstract}
ABSTRAK
Kopi merupakan tanaman perkebunan yang banyak tumbuh dan dikembangkan di Indonesia. Di Indonesia banyak daerah penghasil kopi dengan cita rasanya yang khas. Kabupaten Temanggung adalah salah satu daerah penghasil kopi di Indonesia, namun tidak semua daerah di Kabupaten Temanggung dikenal sebagai penghasil kopi dengan cita rasa yang khas. Salah satu daerah penghasil kopi di Kabupaten Temanggung yaitu Desa Tleter yang terletak di Kecamatan Kaloran. Untuk mengetahui apakah kopi dari Desa Tleter bisa dikembangkan atau tidak maka diperlukan analisis daya saing sehingga akan diketahui keunggulan kompetitif dan keunggulan komparatif dari usaha tani kopi yang sudah dilakukan. Penelitian ini bertujuan untuk mengetahui daya saing kopi di Desa Tleter Kecamatan Kaloran, Kabupaten Temanggung. Metode yang digunakan dalam penelitian ini adalah metode deskriptif kuantitatif. Pengambilan sampel dilakukan secara sengaja (purposive sampling). Jumlah responden dalam penelitian ini sebanyak 40 petani kopi. Pengambilan data dilakukan dengan wawancara menggunakan kuesioner. Analisis daya saing dilakukan dengan menggunakan Policy Analysis Matrix (PAM). Hasil analisis PAM menunjukkan nilai keunggulan kompetitif atau PCR sebesar 0,55 dan keunggulan komparatif atau DRCR sebesar 0,55 artinya kopi di Desa Tleter memiliki daya saing.
\end{abstract}

Kata Kunci : Daya saing kopi, keunggulan kompetitif, keunggulan komparatif, Polycy Analysis Matrix (PAM).

\section{ABTRACT}

Coffee is a plantation that grows and develops in Indonesia. In Indonesia there are many coffeeproducing regions with distinctive tastes. Temanggung Regency is one of the coffee producing regions in Indonesia, but not all regions in Temanggung Regency are known as coffee producers with distinctive flavors. One of the coffee producing areas in Temanggung Regency is Tleter Village, located in Kaloran District. To find out whether coffee from Desa Tleter can be developed or not, competitiveness analysis is needed so that competitive advantage and the comparative advantage of coffee farming will be known. This study aims to determine coffee competitiveness in Tleter Village, Kaloran District, Temanggung Regency. The method used in this research is quantitative descriptive method. The sampling technique is purposive. The number of respondents in this study were 40 coffee farmers. Data retrieval is done by interviewing using a questionnaire. Competitiveness analysis is done by using the Policy Analysis Matrix (PAM). The results of the PAM analysis show the value of competitive advantage or PCR of 0,55 and comparative advantage or DRCR of 0.55 means that coffee in Tleter Village has competitiveness.

Keyword: coffee competitiveness, comparative advantage, competitive advantage, Polycy Analysis Matrix (PAM)

\section{PENDAHULUAN}

Konsep daya saing bisa didefinisikan berbeda oleh setiap orang. Perbedaan tersebut tidak lepas dari pandangan yang ditelaah. Daya saing merupakan suatu kemampuan produk atau komoditas untuk memasuki pasar Nasional atau pasar Internasional. Kemampuan yang dimaksud dalam kontek daya saing adalah kemampuan suatu produk atau komoditas untuk memasuki, bertahan dan bersaing dipasar

terbuka. Daya saing merupakan kemampuan negara untuk memasarkan produk yang dihasilkan terhadap kemampuan negara lain (Porter, 1990). Daya saing diartikan juga sebagai kemampuan suatu perusahaan atau negara dalam mempertahankan pasar yang sudah dimasuki. Kemampuan yang dimaksut adalah kekuatan suatu perusahaan atau negara dalam mempertahankan survai yang 
tepat waktu dan harga yang bersaing secara kompetitif (Rahmana, 2009).

Pada dasarnya suatu wilayah punya kemampuan menghasilkan suatu barang yang memiliki sesuatu yang lebih atau memiliki kekhasan tersendiri dari wilayah yang lain, sehingga harga jualnya akan menjadi lebih tinggi. Daya saing dapat diartikan sebagai kemampuan produsen untuk menghasilkan produk atau komoditas dengan biaya yang relatif rendah, sehingga apabila barang atau komoditi tersebut dijual di pasar kemungkinan besar akan menguntungkan. Kegiatan di bidang pertanian yang bisa meningkatkan daya saing dari suatu produk atau komoditi yaitu melalui kegiatan pembangunan agribisnis. Pembangunan agribisnis dilakukan melalui kegiatan tranformasi keunggulan komparatif menjadi keunggulan kompetitif atau keunggulan bersaing. Indikator yang bisa digunakan untuk mengukur seberapa besar daya saing yang dimiliki suatu komoditi bisa menggunakan dua indikator yaitu keunggulan komparatif dan keunggulan kompetitif (Nuralitas, 2014).

Prinsip keunggulan kompetitif mencakup keunggulan yang berkaitan dengan kualitas, harga, kebijakan dan strategi yang digunakan. Selain itu keunggulan kompetitif bisa digunakan untuk memprediksi selera konsumen dan kepuasan konsumen atas suatu barang atau komoditi. Berbeda dengan keunggulan komparatif, keunggulan komparatif pada dasarnya digunakan untuk mengetahui spesialisasi produksi yang bisa digunakan suatu perusahaan atau negara (Falatehan, 2008).

Dalam upaya peningkatan daya saing kopi di Desa Tleter, Kecamatan Kaloran, Kabupaten Temanggung diperlukan analisis daya saing, yang akan dilihat dari indikator keunggulan kompetitif dan keunggulan komparataif dengan menggunakan alat analisis Policy Analysis Matrix (PAM). Berdasarkan uraian yang sudah dijabarkan dapatdirumuskan masalah yaitu bagaimana daya saing kopi di Desa Tleter, Kecamatan Kaloran, Kabupaten Temanggung. Untuk menjawab masalahtersebut penelitian ini dilakukan dengan tujuan menganalisis daya saing kopi Di Desa Tleter, kecamatan Kaloran, Kabupaten Temanggung.

\section{METODE PENELITIAN}

Metode yang digunakan dalam penelitian ini adalah metode deskriptif kuantitatif. Penelitian ini dilakukan pada bulan April 2018 sampai dengan bulan Mei 2018. Lokasi penelitian di Desa Tleter, Kecamatan Kaloran, Kabupaten Temanggung.Lokasi penelitian ditentukansecara sengaja karena merupakan salah satu sentra penghasil kopi di Kecamatan Kaloran.

\section{Metode Penentuan Sampel}

Metode pengambilan sampel dilakukan secara sengaja (purposive sampling) dengan responden adalah petani kopi di Desa Tleter, Kecamatan Kaloran, Kabupaten Temanggung. Purposive sampling merupakan sebuah teknik pengambilan sampel berdasarkan pertimbangan tertentu (Sugiyono, 2010). Jumlah responden dalam penelitian ini sebanyak 40 petani kopi

\section{Jenis Dan Teknik Pengumpulan Data}

Jenis data yang digunakan dalam penelitian ini adalah data primer dan data sekunder. Data primer didapatkan dari wawancara dengan narasumber utama secara langsung. Wawancara dilakukan degan menggunakan daftar pertanyaan dalam bentuk kuesioner. Data sekunder adalah data yang didapatkan dari intansiintansi yang berkaitan dengan data statistik dan data-data yang berkaitan dengan PAM (Polycy Analysis Matrix). Data sekunder yang dibutuhkan dalam analisis PAM yaitu data harga jual kopi dan harga beli pupuk di pasar internasional. Berikut data dan sumber data sekunder yang diperlukan dapat dilihat pada Tabel 1. 
Irfanda \& Yuliawati, 2019

Tabel 1. Data dan Sumber Data Sekunder

\begin{tabular}{lll}
\hline No & \multicolumn{1}{c}{ Data } & Sumber Data \\
\hline 1 & $\begin{array}{l}\text { Harga jual kopi pada } \\
\text { harga sosial }\end{array}$ & $\begin{array}{l}\text { Comtrade, } \\
\text { Pinksheet }\end{array}$ \\
2 & $\begin{array}{l}\text { Harga Pupuk: SP } \\
\text { 36, ZA dan KCl }\end{array}$ & $\begin{array}{l}\text { Comtrade, } \\
\text { Pinksheet }\end{array}$ \\
5 & $\begin{array}{l}\text { Harga Pupuk } \\
\text { Phonska }\end{array}$ & Alibaba.com \\
\hline
\end{tabular}

\section{Metode Analisis Data}

Penelitian daya saing kopi di Desa Tleter mengunakan analisis Policy Analysis Matrix (PAM). Pengolahan data untuk analisis PAM dapat mengunakan Microsoft Exel. Policy Analysis Matrix digunakan untuk menganalisis keunggulan kompetitif dan keunggulan komparatif yang dilihat dari nilai Private Cost Ratio (PCR) dan Domestic ResourceCost Ratio (DRCR). Dalam analisis PAM data yang diperlukan terbagi menjadi dua data yaitu data finansial (privat) dan data ekonomi (Sosial).

Harga privat adalah tingkat harga yang diterima petani berdasarkan harga aktual yang terjadi dipasar. Satuan ukur yang digunakan untuk mengukur harga privat adalah rupiah (Rp).sedangkan harga sosial adalah harga yang akan menghasilkan alokasi sumber daya terbaik dan dengan sendirinya kan menghasilkan pendapatan tertinggi. Harga sosial juga bisa diartikan sebagai harga yang mengambarkan harga yang sesunguhnya baik faktor input ataupun faktor output. Satuan ukur yang digunakan untuk mengukur harga privat adalah rupiah (Rp). Masing-masing data, baik data privat atau data sosial memilki dua komponen data yaitu input tradable dan input non tradable. Input tradable adalah input yang diperdagangkan dalam perdagangan internasional, seperti pupuk dan petisida. Sedangan input non tradable adalah input yang tidak diperdagangkan secara internasional sehingga tidak memiliki harga di pasar internasional, input non tradable yang dimaksut seperti sewa lahan dan tenaga kerja. Selanjutnya data yang diperoleh akan digunakan untuk mengukur indikator daya saing dari usaha tani kopi yang ada di Desa Tleter. Policy Analysis Matrix (PAM) dan rumus perhitungan yang digunakan dapat dilihat pada Tabel 2 .

Tabel 2. Policy Analysis Matrix (PAM)

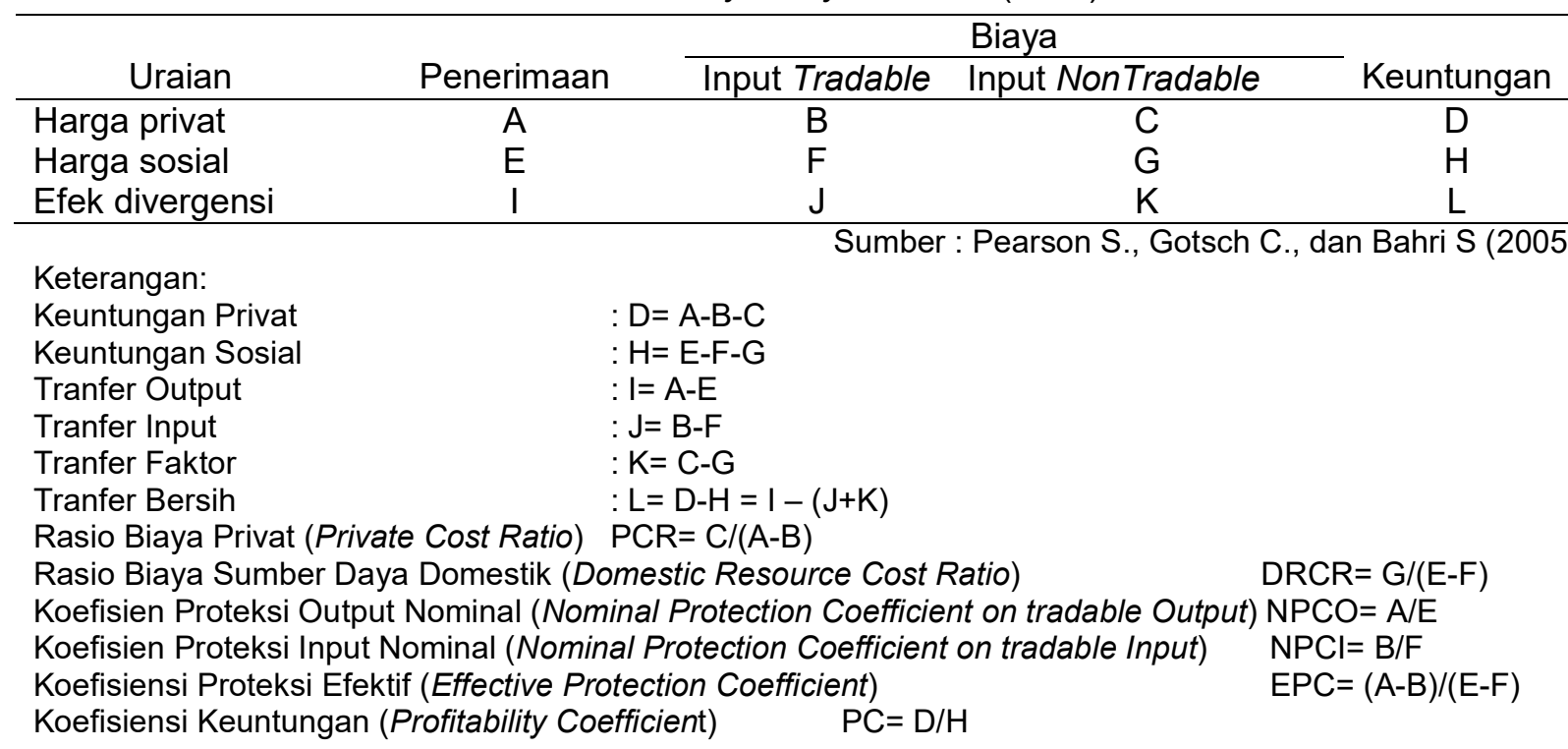




\section{HASIL DAN PEMBAHASAN}

\section{Analisis Daya saing}

Hasil analisis daya saing yang sudah dilakukan menunjukkan bahwa usaha tani kopi yang ada di Desa Tleter memiliki keunggulan kompetitif dan keunggulan komparatif. Hasil analisis PAM disajikan pada Tabel 3.

Tabel 3Analisis PAM usaha tani kopi di Desa Tleter, Kecamatan Kaloran, Kabupaten Temanggung

\begin{tabular}{lcccc}
\hline \multirow{2}{*}{ Uraian } & $\begin{array}{c}\text { Penerimaan } \\
(\mathrm{Rp} / \mathrm{Ha})\end{array}$ & \multicolumn{2}{c}{ Biaya (Rp/Ha) } & Keuntungan \\
\cline { 3 - 4 } & & Input Tradable & Input Non Tradable & $(\mathrm{Rp} / \mathrm{Ha})$ \\
\hline Harga Privat & $75.542 .777,35$ & $4.292 .779,42$ & $39.326 .602,52$ & $31.923 .395,41$ \\
Harga Sosial & $91.428 .634,75$ & $19.518 .594,19$ & $39.326 .602,52$ & $32.583 .438,04$ \\
Efek & & & & \\
divergensi & $-15.885 .857,40$ & $-15.225 .814,76$ & - & $-660.042,63$ \\
\hline
\end{tabular}

Sumber : Data Primer, diolah 2018

Keterangan: kopi dalam bentuk kopi ose

\section{Analisis Keunggulan Kompetitif}

Keunggulan komparatif dalam analisis PAM dapat dilihat dari keuntungan Privat dan Ratio Biaya Privat (PCR). Dari analisis yang sudah dilakukan besarnya keuntungan Privat dapat dilihat pada Tabel 3.Tabel 3 menunjukkan bahwa keuntungan privat usaha tani kopi sebesar Rp 31.923.395,41/Ha. Hasil ini memperkuat hasil penelitian kopi yang dilakukan di Kabupaten Rejang Lebong yang menunjukkan keuntungan privat yang didapatkan sebesar Rp 19.014.458,55/Ha (Murtiningrum, 2013), meskipun terdapat selisih pendapatan privat yang cukup tinggi, hal ini bisa saja terjadi karena harga jual kopi dari tahun ke tahun yang terus mengalami peningkatan. Hasil ini menunjukkan bahwa keuntungan privat dari usahatani kopi di Desa Tleter memiliki nilai positif yang menunjukkan bahwa pasar berada pada posisi persaingan sempurna dan kegiatan usaha tani kopi dapat dilanjutkan karena menguntungkan.

Nilai Ratio Biaya Privat (PCR) usaha tani di Desa Tleter sebesar 0,55. Hasil ini didapatkan dari perhitungan input non tradable biaya privat sebesar $\mathrm{Rp}$ 39.326.602,52 yang dibagi dengan penerimaan privat sebesar $\operatorname{Rp} 75.542 .777,35$ dikurangi oleh input tradable biaya privat sebesar Rp 4.242.779,42. Nilai Ratio Biaya
Privat (PCR) di Desa Tleter memiliki nilai kurang dari satu $(P C R<1)$ yang dapat diartikan bahwa usaha tani kopi yang sudah dijalankan memiliki keunggulan kompetitif. Jika dibandingkan dengan hasil penelitian Murtiningrum (2013) usaha tani kopi di Kabupaten Rejang Lebong memiliki nilai PCR sebesar 0,37 . Hal ini menunjukkan bahwa keunggulan kompetitif usaha tani kopi di Desa Tleter, Kecamatan Kaloran, Kabupaten Temanggung lebih rendah dibandingkan dengan Kabupaten Rejang Lebong. Hasil PCR ini berbeda karena usaha tani kopi di Desa Tleter menggunakan input non tradable lebih tinggi dibandingkan input tradable untuk harga privat. Nilai PCR dari suatu komoditi yang semakin kecil mengindikasikan bahwa usaha tani dari komoditi tersebut memiliki keunggulan kompetitif yang semain besar.

\section{Analisis Keunggulan Komparatif}

Keunggulan komparatif dalam analisis PAM dapat dilihat dari nilai keuntungan sosial dan nilai Ratio Biaya Sumberdaya Domestik (DRCR). Berdasarkan Tabel 3 dapat diketahui bahwa keuntungan sosial usahatani kopi sebesar Rp 32.583.438,04/Ha. Keuntungan sosial dari usaha tani kopi di Desa Tleter lebih tinggi dibandingan dengan keuntungan privat yaitu sebesar $\mathrm{Rp}$ 
31.923.395,41/Ha. Nilai keuntungan sosial yang lebih besar dari keuntungan privat memiliki arti bahwa usaha tani kopi di Desa Tleter lebih menguntungkan apabila tidak adanya campur tangan dalam bentuk intervensi dari pemerintah baik dari input atau output (Murtiningrum, 2013). Dari hasil analisis yang sudah dilakukan dapat diartikan bahwa keuntungan sosial bernilai positif sehingga kegiatan usaha tani kopi di Desa Tleter dapat dilanjutkan karena menguntungkan.

Nilai Rasio Biaya Sumberdaya Domestik (DRCR) usahatani kopi di Desa Tleter sebesar 0,55. Hasil ini didapatkan dari perhitungan input non tradabe/ sosial sebesar $\mathrm{Rp}$ 39.326.602,52 dibagi dengan selisih penerimaan sosial Rp 91.428.634,75 dengan input tradable sosial sebesar $\mathrm{Rp}$ 19.518.594,19. Nilai DRCR menunjukkan kurang dari satu $(D R C R<1)$ sehingga diindikasikan usaha tani kopi di Desa Tleter memiliki keunggulan komparatif.Nilai DRCR yang diperoleh berbeda dengan hasil penelitian Prayuningsih dkk. (2012) tentang daya saing kopi di Kabupaten Jember diperoleh nilai DRCR sebesar 0,4397. Perbedaan nilai DRCR ini bisa terjadi karena adanya perbedaan nilai tukar Rupiah terhadap Dolar.

Berdasarkan hasil analisis nilai PCR dan DRCR yang sudah dilakukan menunjukkan bahwa nilai PCR kurang dari satu $(P C R<1)$ dan DRCR kurang dari satu $(D R C R<1)$. Hasil ini menunjukkan bahwa usaha tani kopi di Desa Tleter, Kecamatan Kaloran, Kabupaten Temanggung memiliki keunggulan kompetitif dan keunggulan komparatif yang dapat diartikan bahwa usaha tani kopi di Desa Tleter mampu bersaingdengan kopi dari daerah lain dan kopi Desa Tleter bisa dijadikan komoditas unggulan.

\section{Analisis Kebijakan Pemerintah Dampak Kebijakan Output}

Kebijakan pemerintah terhadap output dalam analisis daya saing dengan mengunakan alat analisis Policy Analysis Matrix (PAM) dapat dilihat dari dua (2) perhitungan yaitu yang pertama perhitungan nilai Transfer Output (TO) dan yang kedua adalah perhitungan nilai Koefisien Proteksi Output Nominal (NPCO). Nilai Tranfer Output (TO) dapat dilihat pada Tabel 3. Berdasarkan analisis yang sudah dilakukan nilai Tranfer Output (TO) usahatani kopi Di Desa Tleter sebesar - Rp 15.885.857,40/Ha. Nilai Tranfer Output yang negatif dikarenakan penerimaan sosial petani kopi di Desa Tleter lebih besar dibandingkan dengan penerimaan privat, artinya konsumen atau masyarakat dapat membeli produk kopi dengan harga yang lebih murah dari harga yang sebenarnya. Hal ini juga didukung oleh nilai NPCO sebesar 0,82 atau lebih kecil dari satu $(\mathrm{NPCO}<1)$ yang menunjukkan bahwa harga di dalam negeri lebih rendah dari harga di luar negeri (harga internasional). Nilai Tranfer Output yang negatif menunjukkan bahwa implikasi pajak atau tranfer sumber daya yang akan mengurangi keuntungan. Nilai NPCO kurang dari satu $(\mathrm{NPCO}<1)$ mengindikasikan bahwa kebijakan pemerintah untuk petani kopi belum berjalan dengan efektif sehingga terjadi pengurangan penerimaan petani kopi. Pengurangan penerimaan ini terjadi karena tidak adanya proteksi harga privat yang dilakukan oleh pemerintah.

\section{Dampak Kebijakan Input}

Dampak kebijakan input dalam analisis PAM dapat dilihat daritiga (3) perhitungan yaitu perhitungan nilai Tranfer Input (TI), perhitungan nilai Tranfer Faktor (TF) dan perhitungan nilai kebijakan Proteksi Input Nominal (NPCl). Nilai Tranfer Input yang didapatkan di Desa Tleter sebesar -Rp 15.225.814,76/Ha. Nilai Transfer Input ( $\mathrm{TI})$ yang negatif menunjukkan telah terjadi 
implisit pajak atau transfer sumber daya yang menguntungkan petani di Desa Tleter.

Transfer Faktor (TF) di Desa Tleter bernilai nol karena tidak ada perbedaan harga atau upah tenaga kerja untuk input non tradable pada harga privat dan input non tradable pada harga sosial. Nilai nol untuk Transfer Faktor (TF) di Desa Tleter mengindikasikan bahwa besarnya subsidi yang dikeluarkan pemerintah untuk harga input non tradable pada harga privat bernilai sama dengan harga harga input non tradable pada harga sosial.

Dari analisis yang telah dilakukan Nilai Koefisiensi Proteksi Input (NPCl) sebesar 0,219 mengindikasikan bahwa harga di dalam negeri lebih rendah dari harga di luar negeri atau harga sosial. Hal ini terjadi karena ekpor-impor seperti pupuk memilki hambatan. Hambatan dilakukan agar petani mengunakan hasil produksi pupuk dalam negeri atau mengunakan input lokal.

\section{Dampak Kebijakan Input-Output}

Dampak kebijakan pemerintah terhadap input-output dapat dilihat dari empat perhitungan yaitu perhitungan nilai koefisiensi proteksi efektif (EPC), perhitungan nilai transfer bersih (NT), perhitungan nilai koefisiensi keuntungan (PC) dan perhitungan nilai ratio subsidi bagi produsen (SRP). Bedasarkan analisis yang sudah dilakukan didapatkan nilai Koefisiensi Proteksi Efektif (EPC) sebesar 0,99 atau kurang dari satu, menunjukkan bahwa kebijakan pemerintah untuk melindungi produsen tidak berjalan secara efektif. Dapat diartikan juga petani kopi di Desa Tleter kurang mendapatkan perlindungan atau proteksi dari pemerintah sehingga petani tidak memiliki nilai tambah untuk produk yang dihasilkan.

Dari analisis yang sudah dilakukan didapatkan nilai Transfer Bersih (NT) sebesar -Rp 660.042,63/Ha menunjukkan bahwa kebijakan pemerintah yang dilakukan telah membuat keuntungan yang diterima petani lebih kecil bila dibandingan tanpa ada kebijakan atau dapat diartikan bahwa dengan adanya kebijakan yang diterapkan oleh pemerintah, keuntungan petani kopi di Desa Tleter hilang sebesar -Rp 660.042,63 per hektar.

Nilai Koefisieni Keuntungan (PC) di Desa Tleter sebesar 0,98 menunjukkan bahwa koefisiensi keuntungan lebih kecil dari satu $(P C<1)$ meskipun hampir mendekati satu. Hal ini mengindikasikan bahwa kerugian yang diterima petani relatif kecil. Di sisi lain keuntungan yang seharusnya diterima petani menjadi lebih rendah dari yang seharusnya.

Nilai Rasio Subsidi bagi Produsen (SRP) adalah rasio yang digunakan untuk mengukur semua dampak transfer. Dari hasil analisis yang sudah dilakukan didapatkan Nilai Rasio Subsidi bagi Produsen (SRP) sebesar -0,0072. Hasil analisis SRP menunjukan bahwa SRP kurang dari satu(SRP<1). Hasil SRP kurang dari satu atau negatif menunjukkan bahwa kebijakan pemerintah terhadap input-output merugikan petani, karena petani harus membayar biaya imbangan (opportunity cost) lebih tinggi untuk berproduksi yaitu sebesar $0,72 \%$.

\section{KESIMPULAN}

Hasil analisis daya saing dengan Policy Analysis Matrix (PAM) menunjukkan keunggulan kompetitif atau nilai PCR sebesar 0,55 dan keunggulan komparatif atau nilai DRCR sebesar 0,55. Nilai PCR dan DRCR dari usaha tani kopi di Desa Tleter, Kecamatan Kaloran, Kabupaten Temanggung masing-masing kurang dari 1 (PCR dan DRCR < 1) sehingga dapat disimpulan bahwa usaha tani kopi di Desa Tleter, Kecamatan Kaloran, Kabupaten Temanggung memiliki daya saing.

\section{DAFTAR PUSTAKA}

Falatihan, 2014. Analisis
Komparatif $\begin{array}{r}\text { Keunggulan } \\ \text { daan }\end{array}$ Kompetitif
Pengusahaan Komoditi Jagung
Di Kabupaten Grobogan (Studi Kasus:
Desa Panunggalan, Pulokulon,


Irfanda \& Yuliawati, 2019

Kabupaten Grobogan, Jawa Tenggah). Jurnal Agribisnis dan Ekonomi Pertanian (Volume 2. No 1 Juni 2008) Hal:1-15

Murtiningrum, 2013. Analisis Daya Saing Usaha Tani Kopi Robusta (CAFFEA CANEPHORA) Di Kabupaten Rejang Lebong. Journal. Of. Internasional Development, vol 14 : $459-471$

Nuralitas, 2014. Analisis DayaSaing Dan Rumusan Strategi Perkembangan Agribisnis Kopi indonesia. Jurnal Agribisnis Indonesia vol $2 \mathrm{No} 1 \mathrm{Hal}$ : 63-74

Pearson S., Gotsch C., dan Bahri S. 2005. Aplikasi Policy Matrix Pada Pertanian Indonesia. Yayasan Obor. Jakarta.
Porter, 1990. Competitive Advantage Of Nations. NewYork: Word Press

PrayuginingsihH., Santoso Hari T., Hazmi M. 2012. Peningkatan Daya Saing Kopi Rakyat Di Kabupaten Jember. JSEP Vol 6 No. 3 November 2012. Hal ; 2640

Rahmana, 2009. Peranan Teknologi Informasi Dalam Peningkatan Daya Saing Usaha Kecil Menengah. Seminar Nasional Aplikasi Teknologi Informasi 2009 (SNATI 2009) Yogyakarta

Sugiyono, 2010. Metode Penelitian Keungulan Kuantitatif dan RDN. Bandung:

Alfabeta 